\title{
中高年者の精神保健の諸問題
}

\author{
島䓢 安 雄
}

\section{I. 中高年者の精神的状況}

初めに精神保健の観点からみて, 中高年者がど らいら状況におかれているか, といら点にふれて おきたい。

中年は，仕事の上では，まさに油ののりきった 時期ということができよう。もし本人の能力にふ さわしい場所が与えられておれば，働き甲斐のあ る充実した日々を送ることができる。

一方, この時期は, 現場で責任のある地位に立 つことが多く, 責任の重さ, 仕事の過重が本人の 負担となる。従来は, 下働きとして上の指示に従 って真面目に働いていればよかったが，ここでは 部下に心をくばり人望のある上司にならねばなら ない。いわば，上向きの暮しから，下向きの立場 に転換することになる。おた上司と部下の間の調 整役，あるいは板ばさみの立場に追いこまれるこ ともしばしばある。

仕事の内容に関しては, 自分の知らない領域, 不得意な仕事を与えられ，今さら若い部下にきく わけにも行かないといらことで悩んだり, コンピ ニータ化など新しい技術の進歩に対応して行かね ばならない役柄にまわされてもそれをこなせない で煩悶したり，それやこれやで自分の能力を発揮 できず周囲からも評価されない状態におちこんで いる場合がある。このような意味で中年は，そろ そろ自分の限界が見えて来る時期ともいえる。そ して，それに応じて，自己の人生に対する考光方 を変えなければならない，いわば出世を目ざして 外を向いていた洒值観をみなおし，内に向いて新

Mental Health on the Middle- and Old-aged People

国立武蔵療養所・所長

しい心構えを作る必要に迫られるときでもある。 このような危機をのり越えたとしても，次の問 題が待ち受けている。停年と，それに伴ら転職に まつわる諸々のことがらである。仕事を生き甲斐 とし, それ一途に走って来た人が, 従来の職から 離れ新しい生活をらち立てねばならない。また， 他の職に変った場合, 新しい職場や仕事に馴れ, らまく適応して行く必要があるが，これらの転換 がスムーズに行かないことがしばしばある。

家庭の主婦にとっても，この時期は一つの危機 といえよう。家庭の維持, 子供の養育に追われて 無我夢中で送って来た日常生活に，それを顧る余 裕ができて来る。成長した子供は親から離れ，家 庭から遠のき, 頼りにする夫は外の仕事に忙し く, とり残された主婦は, 改めて人生とは何なの だろらかと考觉る。心の中に空間ができ，それを 埋めるための新しい旅立ちが必要になる。また昔 からいわれている嫁・姑の問題, 年老いた親の世 話, 近隣との問題などは, 必ずしもこの年龄層に 限ったものではないが，しばしば大きな負担にな る。

つぎに高年期についてみると，この時期は老年 期をも含むが，老年問題は今後のわが国がかかえ る最も大きな課題の一つであり，至るところで語 られているとおりである。個人の生活の面からみ ると, 社会や職場からの引退, それに伴ら社会的 地位の喪失や交際範囲の縮小, 経済的収入の減 少, 家庭内での中心的な地位の喪失, 嫁や婿との 葛藤, 配偶者との死別, 身体的疾患など, 不安や 孤独感をそそる多くの要因が発生する。統計が示 す老年者の高い自殺率は，彼らが少なからず，む ずかしい立場に置かれていることをもの語るもの といえよう。 


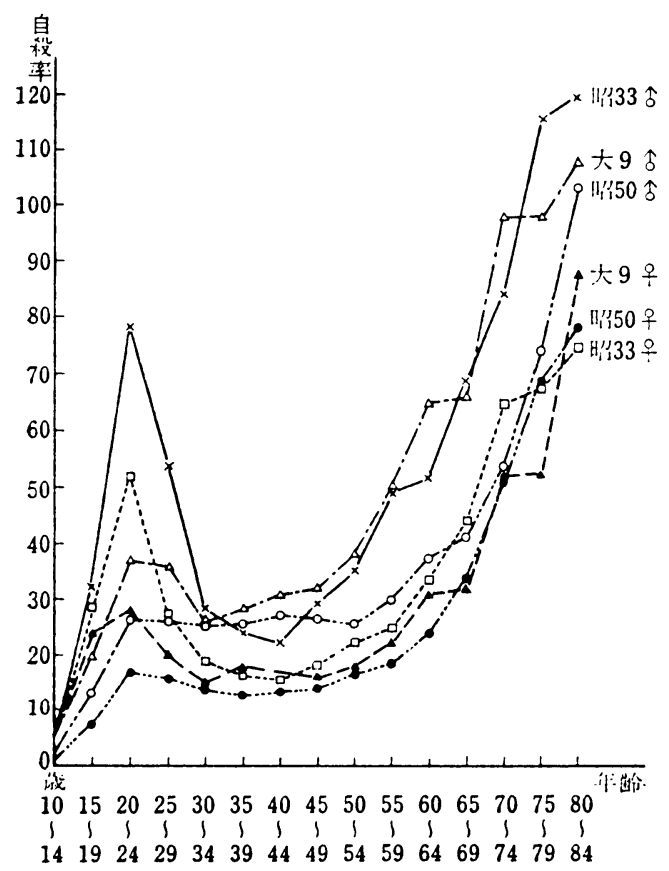

図 1 自殺率の年齢的推移

わが国の大正 9 年, 昭和 33 年, 昭和 50 年におけ る人口 10 万に対する自殺者数を, 男女それぞれに ついて年齢別に示したもの（大原源による）。

図 1 は，人口 10 万に対する自殺者数の年齢分布 を, 大正 9 年, 昭和 33 年, 昭和 50 年について男女 別に示したものである。昭和 33 年頃にみられた青 年期の高いピークは, 近年は減っているが，50歳 頃から高龄に行くに従って急激に増加するという 特徵は変っていない。図 2 は, 年齢別の動向がお よそ 3 つの型に分かれることを示している。年㱓 の上昇と共に自殺率が漸次増加し, しかも60歳以 上で急上昇するハンガリー型, 年齢の上昇と共に 漸次増加するが，60歳台から上は逆に減少するフ ィンランド型に対し，日本型と呼ぶべきものは， 20 歳台前後の小ピークの後, 50 歳台から急上昇し ているものである。この日本型は, 台湾・フィリ ピン・タイなどのアジア諸国と,メキシコ・チリ などの中南米諸国にみられる。

このような自殺率の実態は，高年者が置かれて いる状況のむずかしさの一面を示したものといえ よう。

以上は, 専ら中高年者が経験する心理的状況に ついてふれて来たが，中高年者については当然，

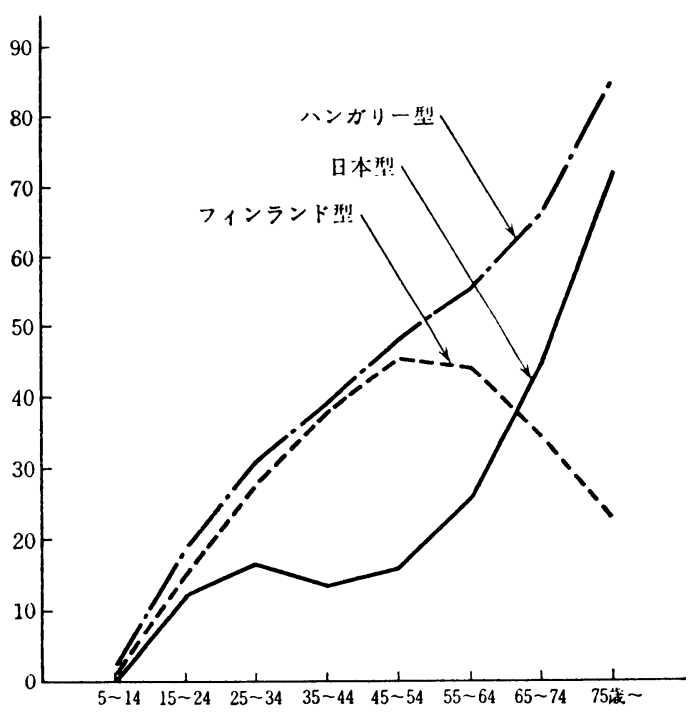

図 2 自殺率の年齢的推移の 3 つの型

年齢による自殺率の変動に 3 つの型があることを 示す (大橋6)による)。

脳も含めて, 身体的な活動力, 体力の低下の問題 も重要である。心理・社会面と身体面の両側面が 互に関連し合って，この年齢層での多くの深刻な 問題を生んでいるといらことができる。

\section{II. 中高年者に多くみられる精神障害}

\section{a. 抑うつ状態}

抑うつ状態を特徵つける基本的な症状は抑うつ 気分と, 考えることや行動がスムーズに行かない こと (抑制) である。これに, 睡眠障害, 朝の起 床時の不快な気分, 1 日のらちで午前中が悪く, 夕方や晚になるといくらかよくなるといら日内変 動, 絶望感と自殺念慮, 食欲・性欲の減退, 疲 労・倦怠感などを伴う。もちろん, 状態像の内容 や, 症状の重さは, 人によって様々で, その本態も いろいろである。ちなみに, 国際疾病分類の第 9 回修正案 ICD-91) の中から抑らつ状態に関係す る主なものをあげるとまず，情動精神病 affective psychoses, 寸なわち従来の躁うつ病にみられるう つ病相がある。躁うつ病といっても, 明らかな躁 病相がなくらつ病相だけがくり返し起こる depressed type の患者, すなわち単極性 monopolar の 経過をとる人と, 躁とらつの両病相を持つ circular type の患者, すなわち双極性 bipolar の経過 
をとる人がいる。この他, 神経症性うつ病 neurotic depression や適応反応の一つとしての, 短い, あるいは遷延する抑らつ反応がある。またストレ スに対する急性反応の中に情性 emotions の障害 を主とするもの, 人格障害の中には情動性の人格 障害 affective personality disorder が含まれてお り,これらの中にも抑らつ状態を呈するものがあ る。すなわち, 従来, 内因性精神病のカテゴリー に入れられて来た躁らつ病のらつ病相の他に, 神 経症性の抑らつ, より急性の抑らつ反応，また抑 らつ的な性格ともいうべきものまでさまざまなも のがある。

定型的ならつ病になりやすい性格としては, Kretschmer が提唱した循環気質がよく知られて いる。内向的で, ぞちらかといえば冷やかな感じ のする分裂気質の人が精神分裂病になりやすいの にひきかえ, 社交的で情性豊か, 現実的な傾向を もった循環気質の人が躁らつ病と近い関係にある といらものである。また 20 年余り前から注目され て来ているものに, Tellenbach が提唱したメラン コリー型 Typus melancholicus と呼ばれる性格が ある。基本的には几帳面さ Ordentlichkeit によっ て支えられて扣り，それの破綻によって抑うつ的 な状態に拈ちこむとされているものであるが，す でに数十年前, これと似た性格の重要性を主張し た人に，下田がいる。彼はこれを「執着性格」と 呼び, 初老期らつ病について書いたものの中で, つぎのように述べている8)。「此種の人は，何事に も徹底的で, いい加減といふことが出来ぬ, 吾々 の様なズボラと違い, やり初めた仕事は徹夜して でも片付けぬと気がすまず，正直で規張面で，正 確で, 義務心・責任感が異常に強いことを特徵と して居り，実務家であって空想家でない。斯様に よい性質であるから，確実な人物として社会の信 用を得ること勿論で，模範社員，模範村長などと 賞められている人は，大抵此性格の持主である」 と。このような性格の人はその長所を生かせない ような状況に追いこまれると抑らつ状態に陥りや すい。

らつ病に関連して近年よく語られるものに仮面 らつ病 masked depression がある。一般に抑らつ 状態では, 精神的な抑らつ気分や心身の活動の渋
滞と共に，様々な身体の訴えがみられる。頭が重 くめまいがする, 視力が落ちた, 耳鳴がする, の ぞがかわく, 胸がつまる, 背中や腰が痛い, 食欲 がなく体重が減った，便秘する，月経が不順にな った，身体がだるく疲れやすい等々，訴えの内容 は全身にわたり，いろいろである。このような身 体的な症状が前景に出て, 精神的な抑らつ症状が 目立たないものがあることが注目され，「仮面う つ病」と名づけられた。症状の周期的な出現, 1 日のらちで午前中が特に悪いという日内変動, 先 に述べたような性格特徵や発病状況, さらに抗う つ剤の投与により目立って改善する，といらよう ないくつかの点から, 基本的にはらつ病であると され，このような病態の存在が一般に認められる よらになった。

高年者の抑らつ状態の病像について, 比較的最 近，よく耳にする言葉に仮性痴呆 pseudodementia といら言葉がある。これは一見, 痴呆状態を思わ せる病状を呈するが, 脳の広範な器質的病変によ る本来の痴呆ではなく, 機能的な精神疾患によっ て痴呆状態とよく似た病態を呈することがある, という事実から生孔た言葉である。とくに，老年 期のらつ病の場合, 記銘・記憶力の低下の訴光, 見当識の混乱, 部分的な知的障害, 反応の遅延な どを示し，また軽いせん妄などの意識障害を呈し たりして, 観察が十分でない場合, 老年ぼけが起 こって来たものととられる場合がある。器質的な 痴呆か, 抑らつ状態によって一見痴呆を思わせる 状態を呈しているのか，といら区別は，治療方 法, 予後判定の上からも大变重要なことであり, その意味では仮性痴呆という命名も意味のあるこ とといえよう。

しかし Pseudodemenz（偽痴呆）といら言葉は 精神医学の領域では古くから全く別の意味に使わ れて来た。その症状は刑務所に拘禁された未決囚 が示すヒステリー性のもらろら状態,すなわち Ganser のもらろら状態の中心をなす症状として 注目されたものである。当然わかっているべき簡 単で平易な質問に答えられなかったり，正しい答 えから少しはずれた応答をするというようなもの で，心因性 psychogenic の，特徵的な症状として 精神医学領域ではすでに定着した概念となってい 
る。そこに，20～30年前から同じ pseudodementia といら言葉が上述の意味で用いられるように なり, 近年, この言葉が，とくに老年医学の領域 で広く使われるようになった。医学用語の概念の 混乱はあちこちで見られるが7)，ここにもその一 例があり，pseudodementia といら言葉をどらい ら意味で使い，あるいは受けとるかといらこと を，その都度，省る必要がある。

抑らつ状態の治療の主体は, 薬物療法と精神療 法である。抗らつ薬はわが国でも10数種類が用い られており，それぞれに若干の特徴を持ってい る。不安を伴ら場合には抗不安薬が併用される。 睡眠薬は, 近年用いられているものは大部分が抗 不安薬と近い構造を持ったもので, 従ってバルビ ッール酸系薬物など，以前主として用いられてい たものと比べると, 遙かに安全度が高い。うつ病 の場合には睡眠障害を伴らことが少なくなく，こ の場合には睡眠薬を上手に使らことが治療上, 大 きな意味を持つ。その他, 躁病に対する薬とされ ているリチウム製剤の持続投与が，らつに対して も治療的，あるいは予防的な効果を持つとされて いる。

他の疾患の場合もそらであるが，とくに抑らつ 状態にある患者は治療者の助けを強く求めてい る。それに対しては，よく話をきいて患者の気 持・苦しみを理解してあげることが第一に必要で ある。身体的に強い痛みなどはなく，患者の置か れている状態は疼痛患者などにくらべれば楽なよ らに思われがちであるが，本格的な抑らつ状態を 経験した患者の中には，「あれほど苦しいものは ない，あの苦しみからみれば身体の痛みなど大し たことはない」といら人がいる。何とか立ちなお り度いともがけばもがく程, ずるずると落ちこみ 苦しんでいる患者の心理にあたたかい接近をする ことが極めて重要である。そらいら意味からいっ て，らつ病だから抗らつ剂を投与すればよいとい らような, 単純な対応のし方は, 厳につつしむべ きものである。

\section{b. アルコール依存}

われわれは日頃，アルコール飲料を適度にと りこれによって日常のストレスを緩和し，ある いは人間関係をより円滑に維持している。その限

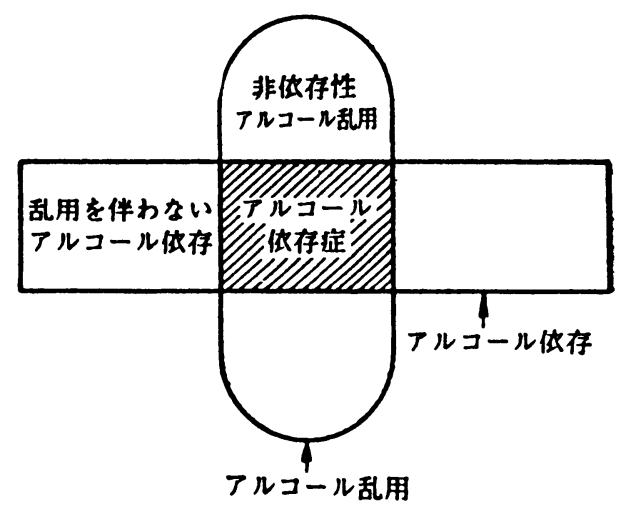

図 3 アルコール依存症の概念

アルコール依存に飲酒行動上の異常（アルコール 乱用）が加わったものを「アルコール依存症」と呼 ぶことを図示したもの（「我が国の精神保健」より

りにおいては飲酒は人生に大きなプラスをもたら しているが，反面，多くのマイナス面を持ってい ることもよく知られている。近年，アルコールの 消費量は次第に増し, わが国の統計でも，20歳以 上の人の年間消費量は昭和 40 年当時にくらべて約 1.6 倍に達している。アルコール依存者とみなさ れるものの数も, 昭和 40 年の約 90 万人に対して, 最近は約 190 万人に達すると推定されている。

アルコールに伴う精神疾患は, アルコール依存 症, アルコール精神病と急性アルコール中毒に分 けられる。

アルコール依存とは, アルコールの精神的効果 を体験するためや，アルコールの影響がきれたた めの不快感を避けるために, 持続的または周期的 に飲酒したいといら強迫的欲求にかられる状態を いう。その中には毎日，晚酎をしないではいられ ないが，その限りでは身体的にも社会的にも何ら 問題がないといら程度のものもあり，このような ものは, ここでいらアルコール依存症には含まれ ない。図 3 に示すように, アルコール依存に加え てアルコール乱用, すなわち飲酒行動上問題があ る場合，例えば，飲酒量を制限しょうと固く決心 しても耐え難い飲酒欲求によってそれが守れない とか, アルコールにもとづく身体疾患, 家族から の拒絶や経済的困窮, 刑事上の問題が発生して子 な敃飲酒を抑えることができないとか，一度飲み はじめると基本的な日常生活すらできないほどに 飲み続け，周期的に飲酒と断酒をくり返すとか, 
連日，飲酒からはじまって酩酊，睡眠，そして覚 醒後また飲酒といらサイクルをくり返すといった よらなものである。このよらな飲酒行動の異常が 続くと,アルコール精神病を抗こして来る。振戦 せん妄はふつうアルコールの影響がきれたとき， すなわち離脱症状として発現するし，アルコール 幻覚症は飲酒間歇時に出現することが多い。これ らの他,アルコール依存徵候を基盤として, 痴呆, コルサコフ精神病，脄妬妄想などが発生する。

ひとたびアルコール依存症やアルコール精神病 に罹患すると，その治療には，本人ばかりでな く, 家族を含めて周囲の人々の根気のよい努力が 必要となる。治療には，医師や看護者ばかりでな く, 地域ケアに当る保健婦, 精神衛生相談員, ケ ースワーカー, さらに福祉関係者や, 民間のボラ ンティア団体の人々の協力が欠かせない。

近年は未成年者の飲酒, 若者の間にみられるイ ッキ飲み現象などが社会的にもとりあげられ，ア ルコールの問題は各年齢層にわたっているが，中 高年者の精神保健の上でも大きな課題である。と くに今後, 中高年の単身生活者がふえていく赹勢 にある中で, その人達の心身の健康維持の観点か らも，十分な対応がなされる必要があるら。

\section{c. 知能の低下 (痴呆)}

中高年期に痴呆を主症状とする病状を呈する疾 患としては, 以前は進行麻疩, すなわち梅毒性の 脳疾患が多数みられたが，これは治療の進歩と共 に急激に減り, 30年程前からは新しい発病の患者 をみることはほとんどなくなった。

それに代って近年, 大きな社会問題となり, 今 後, ますます増加すると思われるのは, 老年期の

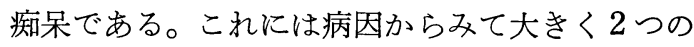
ものが分けられる。一つは脳血管障害によるもの でわが国では老年期の痴呆の50～60\%を占める といわれている。この脳血管性痴呆は多発性の梗 塞を伴うことが多いので, 多発梗塞性痴呆 multiinfarct dementia とも呼ばれる。もら一つの群は 脳の神経細胞が病的に高度に老化するために起こ るもので，30４0\%がこの型に属するといわれて いる。これは老年痴呆またはアルツハイマー型老 年痴呆と呼ばれる。

脳血管性痴呆と老年痴呆の鑑別は X線 CT な
表 1 脳血管性痴呆之老年疾呆の比較 臨床症状と脳波・X線 CT の所見について, 両者

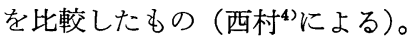

\begin{tabular}{|c|c|c|c|}
\hline & & 脳血管性痴呆 & 老年痴呆 \\
\hline 性 & 差 & 男性に多い & 女性に多い \\
\hline 経 & 過 & 階段状進行, 症状動摇 & 直線的進行 \\
\hline 痴 & 呆 & 斑状痴呆（まだら痴呆） & 全般的痴呆 \\
\hline 病 & 識 & 初期にあり & そしいか欠如 \\
\hline 人 & 格 & 初期にはよく保たれる & $\begin{array}{l}\text { 早期より障害 } \\
\text { されやず }\end{array}$ \\
\hline & 状 & $\begin{array}{l}\text { しばしば頭痛, めまい, } \\
\text { 高血圧,䑈虚血作, 卒中 } \\
\text { 発, 神経学的症状なぞ }\end{array}$ & 少ない \\
\hline & 峜状 & しばしばあり & 明瞭でない \\
\hline 脳 & 波 & 局所異常波出現しやすい & 全般的徐波化 \\
\hline $\mathrm{C}$ & $\mathrm{T}$ & $\begin{array}{l}\text { 大脳表面葁縮および脳室 } \\
\text { 拚大軽度ない等度 } \\
\text { 吸収域を認めることあり }\end{array}$ & $\begin{array}{l}\text { 大脳表面菱縮 } \\
\text { 告さび胵㧓 } \\
\text { 大高度 }\end{array}$ \\
\hline
\end{tabular}

ぞの出現によって，それ以前よりははるかに容易 になったが，臨床的にもそれぞれに特徵がある。 その鑑別を西村4)の表によって示す。表中に「斑 状痴呆」または「まだら痴呆」といら表現がある が，脳血管性痴呆の場合には，血管障害が起こっ た脳部位に対応して知的機能が低下し，その他の 部分の機能は比較的保たれているといらことか ら，老年痴呆に比べて障害がまだら状になるとい ら意味である。

\section{d. 幻覚妄想状態など}

老年期の精神障害については，ぼけや痴呆が広 く関心を持たれているが，それ以外の障害，たと えば, 幻覚妄想状態, 抑らつ状態や神経症・適応 障害のカテゴリーに入れるべきものも少なからず みられる。表 2 は, 国立武蔵療養所の老人病棟を 受持っている宮川3)が，自分の受持患者の中か ら，痴呆や精神分裂病を疑わせる病像を呈してい る患者を除いた13例について，それぞれの診断・ 主症状と，それに多かれ少かれ関連を持つと思わ れる発症前の生活上の背景, さらに個々の症例に 扣いて発症と強い関連があると考学られた諸要因 を，社会・家庭・個人生活に分けて検討すると共 に，その心理的な「内面」の機制を考慮して記入 したものである。表の最も右には入院治療による 転帰と, それに関与した薬物の効果の程度, 生活 背景を改善するためにとった措置があげられてい 


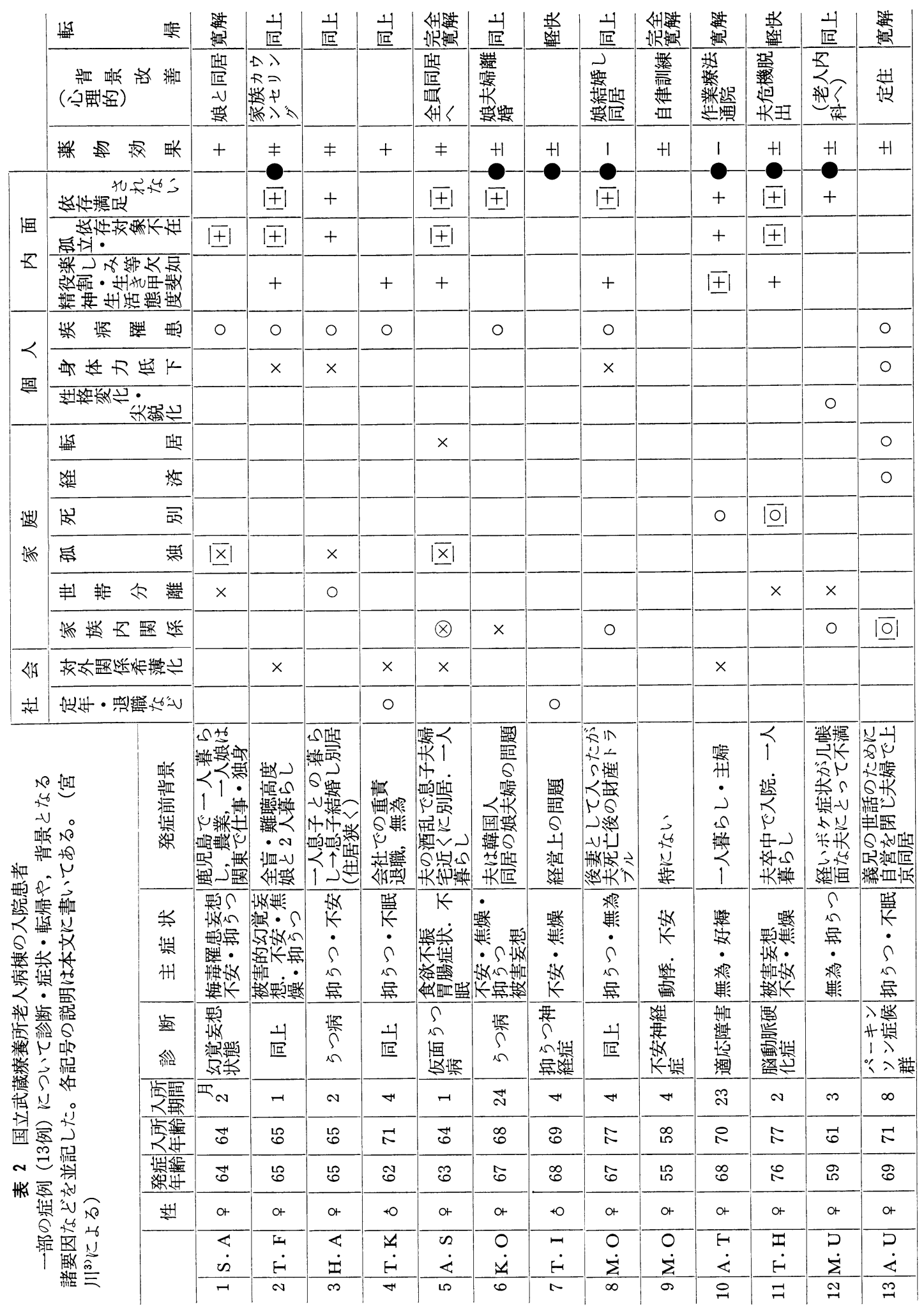


る。中ぬきの白丸が発症の直接の誘因となったも の, ×と+の印は発症に関連の深いもの, 四角に 囲んであるのは入院中にその要因が改善されたこ とを示し，右の方にぬりつぶした丸を付してある のは，入院のさい，本人が入院することを大変い やがった症例である。

この表は種々の生活状沉, 心理的要因が発症に 関連することを示している。「疾病罹患」の項に ○がついている症例は何らかの身体的な病気が他 の心理的要因や背景とからまって発症したと考え られるものであるが，それに該当するものが 7 例 ある。この事実は，身体の病気としてのみ見ず， それが本人の生活のいろいろな面に影響を及ぼす ことを考慮しなければならないことを物語ってい る。

最後に, 81歳の男性患者で, 自分の家にいなが ら，「ここは自分の家ではない，こことそっくり の自分の家は別にある」といらことをいう，珍し い症状を呈した患者9について簡単に述べたい。 昭和58年10月頃よりもの忘れが目立つようにな り，また年金がはいらなくなると心配しはじめ た。11月になると，「ここは自分の家ではない」 といい, 夜間に荷物をまとめて出ていこうとす る。家族がとめてもなかなか聞きいれず，家族の 知らない間に家をとび出し，警察に保護されたこ ともある。本当の家が近くにあると頑固に言い張 るため, 国立武蔵療養所の精神科を受診した。

外来診察時にも，何から何までそっくりの家が もら一軒あり, いつも一泊して今の家に戻ると述 べ，昭和59年 4 月に老人病棟に入院したが， 1 カ 月後には，「あれは錯覚だったかもしれない」と いらょうになり，12月には軽快退院した。

この患者が示した症状は「重複錯誤記憶」と名 づけられるもので大変珍しいものであるが，この ような妄想を持つに至った背景を調べると，かな り理解できる点がある。すなわち, 今の土地と家 は15年前に患者の退職金で購入したもので，土地 が患者名儀，家屋は長男名儀になっていた。年金 生活になってからは財産管理をすべて長男にまか せ，実印も預けていたが，長男が商品相場に手を 出して失敗し, 患者に無断で土地・家屋を抵当に
入れてしまった。長男は負債の責任を問われて銀 行の支店長を解任され, 同じ頃, 妻も突然, 病死 し, 患者は, 「言葉は悪いが, 長男夫婦に裏切ら れたともいえます」と述懐している。

すなわち, この患者に一過性に発生した妄想 は，それに対応する心理的な基盤を持っていたと いえる。老年者の精神障害の発生には, 脳を中心 とする身体諸器官の老化が関与することはいうま でもないが，同時に心理的な面も重視する必要の あることが，この例からもわかる。

\section{III. おわりに}

中高年者に比較的多くみられる精神的な不健康 状態について，若干の実例をあげながら〔本稿で は省略】述べた。これらの精神障害の発症につい ては身体的ないしは生物学的 biological な問題と 心理・社会的 psychosocial な要因がからみ合って いることが少なくないこと，したがって患者の対 応にさいしても，社会の中に拈ける1人の人間と いう，広い観点に立って問題をとらえ，行き届い た配慮をする必要があることを強調したい。

\section{引用文献}

1）保崎秀夫 : 精神障害の分類. 精神医学書（新福・ 島薗編）下巻；1～19，金原出版，1983.

2）厚生省保健医療局精神保健課監修: 我が国の精神 保健（精神保健ハンドブック）昭和60年版, 厚生 環境問題研究会, 1985 .

3）宮川民平：4-1 病棟に入所した老人性精神障害者 の心理的背景について。国立武蔵療養所医局研究 会講演, 1986.

4）西村 健：老年期の痴呆.こころの科学 $5 ； 60$ 〜 $65,1986$.

5）大原健士郎：自殺. 精神医学書（新福・島薗編） 上巻；583 590, 金原出版, 1980 .

6）大橋 薰：自殺 (社会病理学的立場から). 現代 精神医学大系（懸田・大熊・島薗・高橋・保崎 編) $23 \mathrm{~A} ; 151 \sim 166$, 中山書店, 1980.

7）島薗安雄 : 医学用語 [卷頭言].内科 $56 ; 401$, 1985.

8）下田光造 : 初老期罇憂症の話. 下田光造先生論文 集；106 108, 下田光造先生生誕百年 記 念事 業 会, 1985 .

9）須具佑一：高齢老人にみられた重複錯誤記憶, Capgras 症候群との類似性の検討. 老年精神医学 $2 ; 913 \sim 918,1985$. 